\title{
UN CAZ DE ACRODERMATITĂ ENTEROPATICĂ LA COPIL. BOALA DANBOLD-CLOSS
}

\section{Dr Bauer Adalbert, medic primar pediatru, doctor în medicină, SCM Caritas Medica}

În practica pediatrică contemporană orizontul preocupărilor se deplasează tot mai mult spre limitele patologiei altor specialități cu semiologie semnificativă, în unele cazuri determinantă în clinica bolilor infantile.

În acest context $\mathrm{o}$ atenție deosebită trebuie acordată în practica pediatrică curentă unor manifestări clinice cutanate care pot fi expresia clinică evocatoare a unor afecțiuni interne (dismetabolice, genetice, imunologice, patologie de autoagresiune, colagenoze, enzimopatii şi altele) afecțiuni a căror exprimare cutanată coroborată cu simptomatologia clinică de bază, furnizează de multe ori elementul de certitudine în stabilirea diagnosticului de fond. Ele sunt etichetate de clinicieni pediatri de multe ori ca "boli de piele" mai ales la sugar şi copilul mic, ignorând astfel existența unui tablou clinic din patologia infantilă a cărei expresie cutanată o reprezintă.

Prin prezentarea cazului nostru dorim să subliniem importanța celor mai sus menționate.

\section{Discuții. Istoric}

În anul 1936 Brandt descrie o dermatită distinctă la copil, cu alterarea profundă a stării generale consecutivă absorbției defectuoase a alimentelor ingerate. Afecțiunea ca entitate clinică a fost descrisă prima dată de Danbolt şi Closs în anul 1942 sub denumirea de "acrodermatitis enteropatica". Anderson în tratatul său de gastroenterologie infantilă afirmă că boala este foarte rară, cu etiologie necunoscută, probabil cu transmisiune genetică autosomal recesivă. Raritatea afecțiunii este dovedită şi prin faptul ca tratatele de pediatrie prestigioase ca Barnett, Shirkey, Rudolph prezintă o descriere doar de câteva rânduri sumare despre aceasta.

Tabloul clinic conturat al bolii este caracterizat de manifestări cutanate extinse, alopecie generalizată sau circumscrisă, creşterea numărului scaunelor ca simptom obligatoriu asociat de un sindrom de malabsorbție avansată sau în unele cazuri mai moderată.

Tabloul dermatologic inițial este dominat de elemente buloase, ulterior escoriate cu localizare simetrică în regiunea peribucală, perinasală, perianală, la nivelul extremităților, sugerând la prima vedere aspectul unei epidermolize buloase, ectodermoze pluriorificiale Stevens-Johnson, sau a unui impetigo streptococic. Erupțiile cutanate se extind după aceea la nivelul extremităților cu localizare predominantă pe suprafețele de extensie şi suprafețe mari: torace, abdomen.

Erupțiile devin eczematiforme sau cu caracter morfologic de plăci, cu formare de cruste şi placarde psoriaziforme, eritematoase. Suprainfecțiile bacteriene şi cu candida albicans la nivelul suprafețelor muco-cutanate sunt obişnuite.

Diareea survine împreună cu manifestările cutanate. Scaunele în general sunt voluminoase cu caracter steatoreic, fără repercursiuni severe asupra metabolismului hidro-electrolitic. Afecțiunea furnizează mai rar tabloul unei exicoze anhidremice, dar enteropatia cu evoluție trenantă, sindromul de malabsorbție, duc inevitabil la caşectizarea copilului. Malabsorbția lipidelor după Barnett este predominantă ca şi 
în cazul dermatitei herpetiforme. Uneori este evident sindromul de intoleranță la lactoză. Moyhanam (1963) nu pune în evidență modificări histologice ale mucoasei intestinale. Conform studiile lui Bloom (1968) nu se semnalează nici modificări patologice la nivelul pancreasului exocrin.

Căderea părului până la alopecie difuză este una dintre primele şi cele mai evocatoare semne clinice ale afecțiunii.

Afecțiunea poate fi însoțită de sindrom de hipogammaglobulinemie, precum şi scăderea semnificativă a imunoglobulinei A.

Patogenia-sindromului a fost mult timp necunoscută. S-au emis mai multe ipoteze patogenetice care să explice o simptomatologie atât de variată.

În cazurile nediagnosticate şi netratate evoluția este nefavorabilă, letală, în marea majoritate a cazurilor. Conform observațiilor lui Tompkins şi Livingood (1969) s-au semnalat cazuri cu remisiuni spontane la adolescență. Tot ei subliniează şi faptul că în unele cazuri simptomatologia digestivă este minoră, aproape neglijabilă, doar tabloul dermatologic şi alopecia difuză fiind semnele clinice evocatoare.

Diagnosticul pozitiv se poate preciza prin înregistrarea simptomatologiei cutanate caracteristice, a sindromului de malabsorbție, a alopeciei precum şi a răspunsului favorabil la tratament cu preparate de zinc.

\section{Prezentarea cazului.}

Copilul G.I: cu vârsta de 2 ani din mediul rural, a fost adus la serviciul de dermatologie al Spitalului Județean pentru o afecțiune cutanată care a fost tratată în ambulatoriu ca eczemă atopică, dar având în vedere că leziunile cutanate în ciuda tratamentelor aplicate timp de 4 luni au devenit mai extinse şi suprainfectate, se solicită un examen clinic pediatric.

\section{Examenul clinic obiectiv}

Aspectul clinic al copilului este impresionant prin următoarele simptome şi semne:

- stare de hipotrofie marcată-greutate de 6200 grame la vârsta de 2 ani

- edeme extinse impresionante la nivelul membrelor inferioare, a scrotului, în regiunea suprapubiană cu caracter alb-gălbui, care nu păstrează godeu.

- se remarcă prezența unei alopecii difuze, cu păstrarea pe alocuri a unui smoc de păr, care la cea mai mică tracțiune se detaşează de pielea păroasă a capului.

- scaunele sunt lucioase, abundente, de culoare gri, miros fetid, aspect macroscopic de steatoree

- leziunile cutanate cu localizare multiplă şi polimorfă sunt impresionanate, au caracter eczematoid cu bule, impetiginizat, cu secreție purulentă şi miros fetid insuportabil din cauza suprainfecțiilor bacteriene.

- localizarea leziunilor cutanate cu predominență în regiunile peribucale, perinazală, periorbitală şi perianală la prima vedere a sugerat tabloul unei ectodermoze pluriorificiale Stevens-Johnson, dar evoluția cronică a cazului pe de o parte, iar pe de altă parte extinderea laziunilor la nivelul degetelor membrelor superiare şi inferioare, localizarea perionichială, maleolară, periarticulară (genunchiului, calcaneană), sunt contra argumente. Se remarcă localizarea simetrică a leziunilor cutanate, articulare.

- consider semnificativ şi comportamentul copilului, comun celiachiei: indispoziție, hipersensibilitate, instabilitate comportamentală, atitudine de respingere, neîncredere față de mediul în care trăieşte. Toate acestea, însoțite de o anorexie rebelă, alternând cu consumuri capricioase de alimente.

Examinările paraclinice au arătat o hipoproteinemie marcată, hipogammaglobulinemie, valori scăzute de vitamina A, anemie hiposideremică, moderată alterare a funcțiilor hepatice, stetoree calitativă.

Am procedat la investigații comune sindromului de malabsorbție intestinală accesibile pentru laboratoarele noastre: teste pentru malabsorbția grăsimilor, hidraților de carbon, testul sudorii, 
explorarea funcțiilor pancreatice, a digestiei intestinale, evaluarea funcțiilor hepatice, examenul bacteriologic şi parazitar al materiilor fecale; în urma efectuării acestora nu s-au înregistrat modificări.

\section{Diagnosticul pozitiv}

Manifestările cutanate caracteristice asociate cu enterocolită recidivantă, cronică, cu caracter de sindrom de malabsorbție: steatoree, enteropatie cu pierdere de proteine cu edeme marcate întreținute de hipoproteinemia severă, hipotrofie avansată, alopecie difuză, modificări psihice ca în celichie, ne-a permis încadrarea cazului ca o acrodermatită enteropatică descrisă de Danbold-Closs în 1943.

Evoluția fără tratament substitutiv este nefavorabilă, sfârşitul letal survenind în câțiva ani. $\mathrm{Cu}$ tratament evoluția este bună, simptomele cutanate, digestive şi alopecia dispar, persistând însă deficitul staturo-ponderal şi uneori şi pubertar.

Din anul 1974 după ce Maynahan a demonstrat că scăderea zincului plasmatic este responsabilă de apariția simptomatologiei, tot el a propus tratamentul cu o sare zinc (sulfat, gluconat).

\section{Tratament}

Am administrat zilnic 20 de mg de zinc, cuprins în 100 mg sulfat de zinc (doză suficientă pentru a corecta deficitul de zinc) timp de câteva zile şi am obținut rezultate spectaculare. Leziunile cutanate s-au cicatrizat repede, părul a crescut rapid şi a devenit normal (atât ca troficitate cât şi colorație), a dispărut şi sindromul diareic, fosfatazele alcaline au crescut la valori normale. Se subliniează de diferiți autori că administrarea prelungită de zinc nu este nocivă. (Shirkey)

\section{Concluzii}

- Am prezentat o afecțiune foarte rară cu un tablou clinic la limita interdisciplinară dermatologică şi pediatrică.

- Am conturat dificultăţile de diagnostic pe care le-am întâmpinat în delimitarea cadrului nosologic clasic, de altfel foarte caracteristic

- Vindecarea sau chiar supraviețuirea copiilor depinde de precocitatea precizării diagnosticului pozitiv şi de conduită terapeutică corectă.

- Prin prezentarea cazului am reafirmat veridicitatea concepției lui Maynahan (recuperarea lipsei de zinc), cu rezultate terapeutice extrem de spectaculoase, cu vindecare definitivă.

\section{Bibliografie}

1. CH.M:ANDERSON and V:BURKE: Peditric gastro-enterology, pag-1123

2. H.BARNETT: Pediatrix, pag-1588

3. NELSON: Pediatrix, pag-1423

4. M.SHIRKEY: Treatament of disease of children, pag-815

5. TOROK.I.MONATSCHR: Kinderheikunde-1978-4-174

6. MOYNAHAN.E.J.: Lancet-1974-2-399-citat de O.POPESCU

7. O.POPESCU: Patologie pediatrică-editura medicală-1980, pag-118

8. GARETTS.M-J: Pediat.1977-91-3-492

9. DANBOLD N:-CLOSS.K: Acta.Derma,vener,-citat de O.POPESCU, 1940-23-127. 